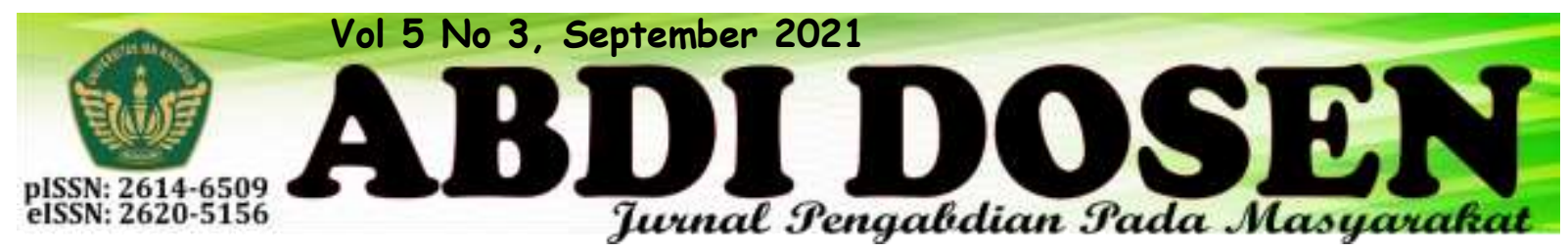

\title{
IMPLEMENTASI PAVING BLOK BERBAHAN SAMPAH PLASTIK DALAM MENGURANGI PENCEMARAN DAN PENINGKATAN PEMAHAMAN LINGKUNGAN PADA PESERTA DIDIK
}

\author{
Abdul Rahman Singkam ${ }^{1}$, Dewi Jumiarni ${ }^{2}$, Befri Ahmad Abdul Ghofur ${ }^{3}$, Muhamad Ridwan ${ }^{4}$, \\ Hefni Dwika Sari ${ }^{*}$, Angga Martias ${ }^{6}$ \\ arsingkam@unib.ac.id ${ }^{1}$, dewij@unib.ac.id ${ }^{2}$, befria.a.ghofur12@gmail.com ${ }^{3}$, mridwan752@gmail.com $^{4}$, \\ hefnidwika@gmail.com ${ }^{5 *}$, anggazizan4386@gmail.com ${ }^{6}$ \\ Dosen Pendidikan Biologi JPMIPA FKIP Universitas Bengkulu ${ }^{1,2}$ \\ Mahasiswa Pendidikan Biologi JPMIPA FKIP Universitas Bengkulu $3,4,5$ \\ PPM Darussalam Kepahiang ${ }^{6}$
}

\begin{abstract}
ABSTRAK
Sampah plastik telah menjadi isu prioritas dunia saat ini. Penggunaan yang masif namun sulit terurai, telah membuat plastik menjadi bahan pencemar utama di darat dan di perairan. Pada kegiatan pengabdian ini kami mengonversi sampah plastik menjadi paving blok sebagai upaya mengurangi pencemaran, dan meningkatkan pemahaman lingkungan pada peserta didik kelas X. Ujicoba pembuatan paving blok ini dilakukan di Kebun Biologi FKIP UNIB, uji daya tekan dilakukan di Fakultas Teknik UNIB, sedangkan praktek konversi dalam kegiatan pembelajaran dilakukan di Madrasah Aliyah Darussalam Kepahiang. Hasil kegiatan menunjukkan bahwa paving blok berbahan plastik memiliki kekuatan tekan yang tidak berbeda dengan paving blok berbahan semen, yaitu $168 \pm 10 \mathrm{~kg} / \mathrm{cm}^{2}$ berbanding $183 \mathrm{~kg} / \mathrm{cm}^{2}$. Konversi menjadi paving blok sangat efektif dalam mengurangi pencemaran sampah plastik di lingkungan karena setiap satu paving blok bervolume $\pm 45 \mathrm{~cm}^{3}$ mampu memerangkap hingga 750 gram sampah plastik. Hasil angket menunjukkan bahwa pengetahuan pengelolaan sampah plastik peserta didik mengalami peningkatan sebesar $\pm 34 \%$ untuk setiap indikator setelah kegiatan pengabdian. Pada skala yang lebih luas, $89 \%$ peserta didik juga menyatakan kegiatan pengabdian ini dapat menambah pemahaman dan wawasan mereka tentang pengelolaan sampah plastik.
\end{abstract}

Kata Kunci: Paving blok; sampah plastik; pencemaran; pengetahuan lingkungan; peserta didik

\section{ABSTRACT}

Plastic waste has been getting a priority issue around the world. Its massive usage but with long term of durability has caused plastic as a main pollutant in land and aquatic system. In this community service agenda, we converted plastic waste on to block paving as an attempt to reduce plastic pollution, and to increase the knowledge of the $10^{\text {th }}$ grade students on environmental issue. Preliminary construction of block paving was conducted in Kebun Biologi FKIP UNIB, and then compressive power test was carried out in Fakultas Teknik UNIB, while application as a learning material was performed in Madrasah Aliyah Darussalam Kepahiang. Result of compressive power test showed the plastic block paving 
has a similar strength in comparison to the cement made one, i.e. $168 \pm 10 \mathrm{~kg} / \mathrm{cm}^{2}: 183 \mathrm{~kg} / \mathrm{cm}^{2}$. This conversion method is very effective to reduce plastic waste in the environment as each \pm $45 \mathrm{~cm}^{3}$ block paving can lock up 750 gram of plastic waste. Result of the questionnaire showed that the environmental knowledge among the students have a drastic increasing, i.e. up to $34 \%$ on average for each indicator. On a wider scale, $89 \%$ of students testify that this community service activity increases their concern and insight on plastic waste management.

\section{Keywords: Paving block; plastic waste; pollution; environmental understanding; students}

\section{PENDAHULUAN}

Sampah plastik adalah permasalahan global yang tidak hanya dijumpai di Indonesia. Total produksi sampah plastik dunia pada tahun 2015 adalah sebesar 6300 juta ton dengan produksi terbesar dari China (Geyer et al., 2017). Indonesia menjadi negara penyumbang kedua dengan total produksi sebesar 64 juta ton/tahun, atau setara dengan $0.7 \mathrm{~kg} /$ orang/hari (Jambeck et al., 2015). Setiap tahun, sekitar 1 juta ton sampah plastik dari Indonesia memasuki lautan (Jambeck et al., 2015). Sampah plastik telah ditetapkan sebagai prioritas utama dalam pengelolaan lingkungan dunia (Borrelle et al., 2020; Klemeš et al., 2020).

Sampah plastik menjadi masalah besar karena penggunaannya yang masif namun sulit terurai di lingkungan. Plastik diperkirakan membutuhkan 100 hingga 500 tahun hingga dapat terdekomposisi (terurai) dengan sempurna. Kegiatan pembakaran sampah plastik bukanlah suatu solusi karena akan menghasilkan gas yang mencemari udara dan membahayakan pernafasan. Sampah plastik yang dibuang ke tanah dan perairan akan terurai menjadi mikro dan nano plastik yang berakibat lebih parah (Mattsson et al., 2015; Blair et al., 2017). Menurut Mattsson et al., (2015) luas permukaan satu kantong plastik belanjaan yang terurai menjadi nanoplastik berdiameter $40 \mathrm{~nm}$ dapat mencapai 2600 m2. Pertambahan luas permukaan yang sangat besar ini akan meningkatkan peluang infiltasi plastik ke tubuh makhluk hidup melalui makanan dan minuman, dan menjadi racun sepanjang hidup di dalam tubuh organisme (Mattsson et al., 2015; Blair et al., 2017). Partikel plastik di dalam tubuh makhluk hidup ini juga akan menjadi racun berantai sesuai urutan rantai makanan.

Persoalan pencemaran sampah plastik terutama pada plastik kemasan sekali pakai. Berbeda dengan plastik tipe botol yang telah banyak didaur ulang dan digunakan kembali, sebagian besar plastik kemasan masih dibuang ke lingkungan. Plastik sekali pakai ini mencakup kantong plastik belanjaan aneka ukuran, pembungkus aneka makanan dan minuman dari pabrik, usaha rumah tangga dan kaki lima, dan lain sebagainya. Metode umum yang digunakan untuk pengelolaan sampah plastik sekali pakai ini hanyalah dengan metode landfill. Metode landfill ini adalah dengan menimbun sampah plastik di dalam tanah sehingga pergerakan partikel menjadi lebih terbatas, sehingga efek negatif dapat lebih diminimalkan. Namun, metode landfill ini juga tidak efektif karena keterbatasan lahan dan pencemaran oleh partikel plastik ke perairan sekitar. Beberapa contoh tempat pembuangan akhir (TPA) yang gagal menggunakan konsep landfill adalah TPA Bantar Gebang di Bekasi dan TPA Air Sebakul di Kota 
Bengkulu.

Metode populer yang digunakan dalam penanggulangan sampah plastik sekali pakai ini adalah penekanan pada konsep 3R (Reuse, Reduce, Recycle). Reuse berarti menggunakan kembali, reduce adalah mengurangi pembelian atau penggunaan, dan recycle adalah mendaur ulang barang-barang yang terbuat dari plastik. Aturan terbaru untuk reduce dari pemerintah Indonesia adalah mewajibkan konsumen membayar untuk setiap kantongan plastik yang digunakan. Hal ini mungkin akan efektif untuk plastik berbentuk kantongan, namun tidak untuk plastik kemasan dari pabrik atau usaha rumah tangga. Beberapa penelitian yang terkait konsep recycle adalah konversi sampah plastik menjadi bahan bakar minyak dan bahan bangunan (Ermawati, 2011; Ragaert et al., 2017).

Pada pengabdian ini kami mencoba mengurangi masalah pencemaran sampah plastik di lingkungan dengan mengkonversi plastik sekali pakai menjadi paving blok. Pembuatan paving blok dari campuran sampah plastik dengan pasir ini telah diuji dan dipraktekkan pada berbagai penelitian antara lain Ariyadi (2019) dan Indrawijaya (2019), sehingga merupakan penerapan produk IPTEKS. Ide ini juga sudah kami uji cobakan pada MTs JaAlhaq di Bengkulu (https://youtu.be/8IR9Mycyms) dengan berbagai tuntutan penyempurnaan. Kualitas paving blok campuran sampah plastik ini memiliki sturuktur yang lebih ringan, namun dengan daya lenting yang lebih besar dibanding paving blok dari tanah atau semen (Basuki \& Darmanijati, 2018; Indrawijaya, 2019).

Kelemahan yang kami temukan saat uji coba pembuatan paving blok ini adalah asap yang dihasilkan dari pencairan plastik kemungkinan berbahaya bagi kesehatan.
Gas utama yang dihasilkan dari proses pencairan plastik tipe polietilen adalah karbon monoksida dan akrolein (Levin, 1987). Karbon monoksida dikenal sebagai gas dengan afinitas tinggi terhadap haemoglobin sehingga dapat mengganggu pengangkutan oksigen pada sistem peredaran darah. Akrolein pada dosis rendah dapat menghambat poliferasi sel paru-paru manusia, sedangkan pada dosis tinggi dapat memicu kerusakan gen pada Drosophila dan kematian sel pada manusia (Kehrer \& Biswal, 2000). Namun penghancuran plastik dengan sistem pelelehan ini tetap lebih aman dibanding metode pembakaran (Ragaert et al., 2017).

Mengatasi masalah asap ini, peralatan pada pelaksanaan pengabdian ini kami coba lengkapi dengan cerobong pendingin. Cerobong ini berfungsi mengkonversi asap menjadi limbah cair sehingga tidak mencemari udara. Meskipun limbah cair hasil konversi ini dapat digunakan sebagai bahan bakar alternatif (Ermawati, 2011; Salamah \& Aktawan, 2016), namun proses pemurnian limbah cair tersebut belum memungkinkan untuk dilaksanakan dalam kegiatan ini.

Pembuatan paving blok ini juga dapat menjadi salah satu contoh konstektual pembelajaran tentang pencemaran di lingkungan tingkat sekolah lanjutan pertama (SLTP) dan atas (SLTA). Salah satu materi pada Biologi kelas satu pada SLTP dan SLTA adalah tentang pencemaran lingkungan. Kompetensi dasar (KD) untuk materi pencemaran ini di SLTA adalah KD 3.11. Menganalisis data perubahan lingkungan, penyebab, dan dampaknya bagi kehidupan; dan KD 4.11. Merumuskan gagasan pemecahan masalah perubahan lingkungan yang terjadi di lingkungan sekitar. Sedangkan untuk tingkatan SLTP, KD yang terkait adalah 
KD $\quad 3.8$ Menganalisis terjadinya pencemaran lingkungan dan dampaknya bagi ekosistem. Indikator dari beberapa $\mathrm{KD}$ ini adalah peserta didik mampu memahami pencemaran lingkungan dan melakukan upaya pengelolaan lingkungan pada tingkat sekolah.

Praktek pembuatan paving blok dari sampah plastik ini memiliki keunggulan kontekstual karena menggunakan sampah dari kehidupan sehari-hari peserta didik.

\section{METODE PELAKSANAAN}

Kegiatan pengabdian ini akan dilakukan di MTs/MA Yayasan Al Akhsyar Pondok Pesantren Modern Darussalam Kepahiang. Sekolah ini dipilih karena menerapkan sistem boarding school sehingga produksi sampah plastik akan lebih tinggi dibanding sekolah biasa. Selain itu, sistem boarding school memungkinkan waktu yang lebih luang bagi peserta didik-siswi untuk melakukan kegiatan praktikum. Sistem pengelolaan sekolah yang mandiri memungkinkan program ini dapat dilakukan secara berkelanjutan sesuai dengan kebutuhan paving blok pengembangan sekolah. Produk yang dihasilkan ini juga diharapkan dapat membantu keuangan yayasan. Jarak dari Universitas Bengkulu ke sekolah ini adalah sekitar $55 \mathrm{~km}$ dengan jarak tempuh sekitar 1,5 jam. Sekolah ini memiliki sekitar 800an peserta didik dan sekitar 70an guru.

Proses pembuatan paving blok dari sampah plastik ini mengacu pada Ariyadi, (2019; Indrawijaya et al., 2019) dengan beberapa modifikasi. Adapun modifikasi yang dilakukan adalah mengganti komposisi (perbandingan) antara plastik, pasir dan koral. Perubahan komposisi ini bertujuan untuk memperbanyak penyerapan sampah plastik. Prosedur kerja
Paving blok yang dihasilkan pun dapat dimanfaatkan pada lingkungan sekitar peserta didik. Selain sebagai salah satu media ajar, kegiatan ini juga diharapkan dapat memicu kecakapan sifat peduli lingkungan pada seluruh komponen yang terlibat. Selain itu, dalam jangka panjang, konversi sampah plastik menjadi paving blok ini akan dapat meningkatkan nilai jual sampah plastik bekas pakai tersebut.

yang dilakukan adalah sebagai berikut:

\section{Tahapan ujicoba}

Pada tahap ini dilakukan ujicoba pengabdian sebelum dijadikan media praktikum di hadapan peserta didik. Alat utama yang dibutuhkan dalam ujicoba ini adalah sumber energi berupa gas elpiji 3 $\mathrm{kg}$, tungku, wadah pelelehan sampah plastik, instalasi pendingin, dan cetakan paving blok. Sedangkan bahan yang dibutuhkan adalah sampah plastik yang telah kering, pasir sungai, sarung tangan kain, dan baskom pendingin berisi air.

Wadah pelelehan plastik berupa tabung silinder berdiameter $50 \mathrm{~cm}$ dan tinggi $90 \mathrm{~cm}$ diletakkan di atas tungku dan dihubungkan dengan cerobong pendingin. Cerobong pendingin berbentuk $\mathrm{S}$ mendatar dimasukkan ke dalam baskom berisi air yang berfungsi sebagai kondensor/penurun suhu sehingga bentuk uap pemanasan plastik terkondensasi menjadi cair. Ujung cerobong pendingin dimasukkan ke dalam baskom berisi air untuk memastikan asap yang mengalir ke udara seminimal mungkin.

Penggunaan tabung diameter $50 \mathrm{~cm}$ ini kurang efektif karena membutuhkan pemanasan yang lama dan tidak cukup dilakukan dengan tungku biasa. Wadah pelelehan kemudian diganti dengan kaleng 
kue bekas berdiameter $15 \mathrm{~cm}$ dengan tinggi $18 \mathrm{~cm}$. Ujicoba dengan wadah ini dapat menghasilkan produk, namun waktu pemanasan yang dibutuhkan cukup lama yaitu hingga 80 menit untuk sekitar 750 gr cacahan sampah plastik. Waktu pelelehan yang terlalu lama ini kemudian disiasati dengan mengganti wadah pelelehan dengan panci presto ukuran 3L berdiameter $18 \mathrm{~cm}$. Panci presto ini merupakan wadah yang efektif, namun sebagai akibatnya instalasi pendigin perlu disetting ulang. Asap yang keluar dari panci presto belum dapat dialirkan ke instalasi pendingin sehingga masih mengalir ke udara. Proses pelelehan plastik menjadi hanya 40 menit.

Setelah proses pelelehan dianggap memadai, maka dilakukan beberapa komposisi campuran antara plastik dengan pasir sebagai berikut: a). $\mathrm{P} 1=750 \mathrm{gr}$ plastik: 300 gr pasir; b). P2= 750:400; c). $\mathrm{P} 3=750: 500$; d). P4= 750:600; dan e). P5= 750:750. Penambahan pasir bertujuan untuk menambah daya kekuatan paving blok. Pada setiap perbandingan ditambahkan oli bekas sebanyak $200 \mathrm{ml}$. Oli bekas ini sebagai media pelarut plastik sehingga dapat tercampur lebih merata dengan pasir. Pasir 300 gr sebagai dosis terendah, karena pada perbandingan ini paving blok sdh mengapung di air. 1:1 sebagai perbandingan tertinggi dengan mengacu pada Ariyadi (2019). Masing2 perlakuan dengan tiga ulangan. Kekuatan blok berbagai kombinasi ini kemudian diuji dengan alat tekan di laboratorium terpadu Fakultas Teknik Universitas Bengkulu. Kekuatan berbagai paving blok berbahan plastik ini dibandingkan dengan paving blok berbahan semen (P0) sebagai pembanding.

\section{Tahapan sosialisasi dan pemanfaatan sebagai media pembelajaran}

Metode pembuatan paving blok berbahan plastik ini kemudian dijadikan sebagai media pembalajaran biologi kelas $\mathrm{X}$ topik lingkungan di Madrasah Aliyah Pondok Pesantren Modern Darussalam Kepahiang. Kompetensi dasar (KD) terkait adalah KD 3.11. Menganalisis data perubahan lingkungan, penyebab, dan dampaknya bagi kehidupan; dan KD 4.11. Merumuskan gagasan pemecahan masalah perubahan lingkungan yang terjadi di lingkungan sekitar. Tahapan ini meliputi tiga proses: 1). Penjelasan ke murid-murid tentang permasalahan sampah plastik dan solusi yang mungkin dilakukan beserta pengisian kuisioner pra kegiatan; 2). Praktikum pembuatan paving blok berbahan plastik; 3). Penutup berupa penguatan tentang tujuan kegiatan yang dilakukan, tanya jawab, dan pengisian kuisioner pasca kegiatan.

Kuisioner pra kegiatan memiliki 10 pertanyaan, dengan pilihan jawaban iya atau tidak. 10 pertanyaan tersebut adalah:

1. Saya pernah mendengar tentang konversi sampah plastik menjadi paving blok/beton/aspal;

2. Saya pernah mendengar tentang cara konversi sampah plastik menjadi paving blok/beton/aspal;

3. Saya tahu cara melakukan konversi sampah plastik menjadi paving blok/beton/aspal;

4. Saya pernah melakukan konversi sampah plastik menjadi paving blok/beton/aspal;

5. Saya tahu tentang peluang usaha konversi sampah plastik menjadi paving blok/beton/aspal;

6. Saya tahu kendala-kendala usaha konversi sampah plastik menjadi 
paving blok/beton/aspal;

7. Saya berpikir konversi sampah plastik menjadi paving blok/beton/aspal mudah untuk dilakukan;

8. Saya berpikir untuk mempraktekkan konversi sampah plastik menjadi paving blok/beton/aspal secara mandiri/sendiri;

9. Saya bersedia untuk memberikan informasi konversi sampah plastik menjadi paving blok/beton/aspal ke orang lain;

10. Saya memahami bahwa kegiatan konversi sampah plastik menjadi paving blok/beton/aspal bermanfaat positif untuk lingkungan.

Pertanyaan ini kemudian diulang pada kuisioner pasca kegiatan, dan ditambah dengan lima pertanyaan besifat pemahaman akan wawasan lingkungan berskala 1 (tidak paham) sampai 5 (sangat paham). Kelima pertanyaan tersebut adalah:

\section{HASIL dan PEMBAHASAN}

Hasil uji ketahanan menunjukkan bahwa paving blok berbahan plastik memiliki kekuatan yang tidak jauh berbeda dibanding paving blok berbahan semen. Nilai kekuatan menahan beban pada paving blok semen memang lebih tinggi, namun saat nilai ini dibagi dengan berat paving blok untuk menghitung nilai kuat
1. Materi mampu mengungkap manfaat konversi sampah plastik menjadi paving blok/beton/aspal bagi lingkungan yang lebih bersih;

2. Materi pelatihan mencerahkan dan membuat saya memahami pentingnya penanganan sampah plastik;

3. Materi pelatihan membuka wawasan saya tentang usaha-usaha yang dilakukan untuk menanggulangi sampah plastik;

4. Materi pelatihan membuat saya paham cara penanganan sampah plastik yang benar;

5. Materi pelatihan ini membuat saya dapat mengajarkan cara penanganan sampah plastik ke orang lain.

Alat-alat yang yang digunakan untuk membuat paving blok kemudian diserahkan ke pihak sekolah/yayasan agar pembuatan paving blok dari sampah plastik ini dapat dilakukan secara berkelanjutan oleh pihak sekolah/yayasan.

tekan, maka nilai kuat tekan paving blok berbahan semen menjadi jauh lebih kecil. Jika dilakukan standarisasi (konversi) berat antara paving blok berbahan semen dengan berbahan plastik, maka nilai keduanya menunjukkan angka yang tidak terlalu berbeda yaitu $183 \mathrm{~kg} / \mathrm{cm}^{2}$ berbanding $168 \pm 10 \mathrm{~kg} / \mathrm{cm}^{2}$ (Tabel 1). 
Tabel 1. Perbandingan nilai kuat tekan paving blok berbahan plastik dan semen

\begin{tabular}{|c|c|c|c|c|c|c|c|c|}
\hline \multirow{2}{*}{ No. } & \multirow{2}{*}{ Kode } & \multirow{2}{*}{$\begin{array}{l}\text { Umur } \\
\text { (hari) }\end{array}$} & \multirow{2}{*}{$\begin{array}{c}\text { Berat } \\
\text { (kg) }\end{array}$} & \multirow{2}{*}{$\begin{array}{l}\text { Luas } \\
\left(\mathrm{cm}^{2}\right)\end{array}$} & \multirow{2}{*}{$\begin{array}{c}\text { Volume } \\
\left(\mathrm{cm}^{3}\right)\end{array}$} & \multirow{2}{*}{$\begin{array}{c}\text { Beban } \\
(\mathbf{k N})\end{array}$} & \multicolumn{2}{|c|}{ Kuat Tekan $\left(\mathrm{kg} / \mathrm{cm}^{3}\right)$} \\
\hline & & & & & & & Absolut & Konversi* \\
\hline 1 & KA & 3 & 2.19 & 681.82 & 3340.91 & 209.20 & 31.30 & 173.86 \\
\hline 2 & KB & 3 & 2.15 & 707.31 & 3395.07 & 316.40 & 45.63 & 169.11 \\
\hline 3 & $\mathrm{KC}$ & 3 & 2.17 & 698.76 & 3354.04 & 361.40 & 52.75 & 206.25 \\
\hline 4 & $3 \mathrm{~A}$ & 3 & 0.47 & 7.06 & 43.32 & 65.00 & 939.64 & 202.52 \\
\hline 5 & 3B & 3 & 0.49 & 7.06 & 42.34 & 41.90 & 605.71 & 138.11 \\
\hline 6 & $3 \mathrm{C}$ & 3 & 0.50 & 6.42 & 38.51 & 50.10 & 796.27 & 183.19 \\
\hline 7 & $4 \mathrm{~A}$ & 3 & 0.58 & 6.54 & 39.26 & 24.50 & 381.94 & 100.98 \\
\hline 8 & $4 \mathrm{~B}$ & 3 & 0.55 & 6.54 & 39.26 & 50.00 & 779.47 & 177.73 \\
\hline 9 & $4 \mathrm{C}$ & 3 & 0.58 & 7.06 & 42.34 & 19.00 & 274.67 & 73.57 \\
\hline 10 & $5 \mathrm{~A}$ & 3 & 0.53 & 6.80 & 40.78 & 45.00 & 675.30 & 164.66 \\
\hline 11 & $5 B$ & 3 & 0.39 & 6.93 & 41.55 & 50.70 & 746.69 & 170.25 \\
\hline 12 & $5 \mathrm{C}$ & 3 & 0.57 & 6.80 & 40.78 & 51.60 & 774.35 & 202.42 \\
\hline 13 & $6 \mathrm{~A}$ & 3 & 0.58 & 6.80 & 40.78 & 53.80 & 807.36 & 214.56 \\
\hline 14 & $6 \mathrm{~B}$ & 3 & 0.58 & 7.06 & 42.34 & 46.90 & 677.99 & 154.59 \\
\hline 15 & $6 \mathrm{C}$ & 3 & 0.55 & 7.06 & 42.34 & 42.70 & 617.27 & 157.38 \\
\hline 16 & $7.5 \mathrm{~A}$ & 3 & 0.58 & 6.80 & 40.78 & 50.30 & 754.84 & 201.29 \\
\hline 17 & $7.5 \mathrm{~B}$ & 3 & 0.58 & 6.67 & 40.02 & 56.70 & 867.17 & 197.72 \\
\hline 18 & $7.5 \mathrm{C}$ & 3 & 0.48 & 7.06 & 42.34 & 56.80 & 821.10 & 179.82 \\
\hline
\end{tabular}

$\mathrm{K}=$ kontrol berupa paving blok semen; 3, 4, 5, 6, $7.5=$ kombinasi perlakuan berupa 300 gr pasir: 750 gr sampah plastik; 400 gr pasir:750 gr sampah plastik dan seterusnya. $\mathrm{ABC}=$ ulangan 1,2 dan 3. Berat plastik yang digunakan untuk semua perlakuan selain kontrol adalah 750 gram. *Nilai kuat tekan distandarkan terhadap berat bahan

Hasil angket pengetahuan peserta didik tentang konversi sampah plastik menjadi paving blok menunjukkan pengetahuan awal peserta didik berada pada kisaran 3-76\% (Gambar 1). Nilai terendah diperoleh untuk indikator keempat yaitu apakah para peserta didik sudah pernah melakukan konversi sampah plastik menjadi paving blok, tembok, atau aspal. Hanya satu dari 37 peserta didik yang menjawab telah pernah melakukan konversi sampah plastik menjadi paving blok, tembok, atau aspal. Nilai tertinggi diperoleh untuk kategori ke-10 yaitu apakah peserta didik memahami bahawa kegiatan konversi paving blok bermanfaat atau tidak. Pada kategori ini, 28 dari 37 peserta didik meyakini bahwa kegiatan konversi sampah plastik menjadi paving blok, tembok, atau aspal akan memberi pengaruh positif bagi lingkungan.

Hasil angket pengetahuan peserta didik ini meningkat drastis dengan ratarata sebesar $34 \%$ untuk setiap indikator. Peningkatan tertinggi diperoleh pada indikator keempat yaitu sebesar 59\%. Peningkatan terendah didapat pada butir ketujuh dan sepuluh, masing-masing sebesar $11 \%$. Pertanyaan untuk butir ketujuh adalah apakah konversi sampah plastik menjadi paving blok mudah dilakukan. Hasil angket ini menunjukkan bahwa kegiatan pengabdian ini mampu meningkatkan pengetahuan peserta didik tentang pelaksanaan dan manfaat konversi sampah plastik menjadi paving blok dengan rata-rata peningkatan sebesar $34 \%$. 




Gambar 1. Peningkatan nilai pengetahuan peserta didik mengenai konversi sampah plastik menjadi paving blok antara sebelum dan sesudah kegiatan.

Pada skala yang lebih luas, kegiatan pengabdian ini dapat menambah pemahaman dan wawasan peserta didik tentang pengelolaan sampah plastik (Tabel 2). Saat skor pemahaman dan wawasan dibuat dalam rentang satu (tidak paham sama sekali) sampai lima (sangat paham), lebih dari $89 \%$ peserta didik menyatakan pemahaman mereka berada pada tingkatan paham (angka empat) dan sangat paham (angka lima). Pengecualian angka 89\% ini hanya pada indikator kelima, yaitu "apakah melalui adanya materi pelatihan ini peserta didik dapat mengajarkan cara penanganan sampah plastik ke orang lain?" Pada indikator kelima ini, sekitar $14 \%$ peserta didik menyatakan masih raguragu (angka 3) untuk dapat mengajarkan cara penanganan sampah plastik ke orang lain. Sekitar $7 \%$ yang lain bahkan menyatakan mereka tidak dapat mengajarkan cara penanganan sampah plastik ke orang lain.

Tabel 2. Persentase pemahaman peserta didik tentang permasalahan sampah plastik beserta cara penanggulannya setelah kegiatan pengabdian

\begin{tabular}{|l|c|c|c|c|c|}
\hline \multirow{2}{*}{ Indikator Pemahaman } & \multicolumn{5}{|c|}{ Persentase Respon (\%) } \\
\cline { 2 - 6 } & $\mathbf{1}$ & $\mathbf{2}$ & $\mathbf{3}$ & \multicolumn{1}{c|}{$\mathbf{5}$} & $\mathbf{5}$ \\
\hline Memahami manfaat konversi sampah plastic & 0.00 & 0.00 & 7.14 & 25.00 & 67.86 \\
\hline Memahami pentingnya pengelolaan sampah plastic & 0.00 & 0.00 & 3.57 & 32.14 & 64.29 \\
\hline $\begin{array}{l}\text { Menambah wawasan tentang upaya } \\
\text { penanggulangan sampah plastic }\end{array}$ & 0.00 & 0.00 & 10.71 & 14.29 & 75.00 \\
\hline $\begin{array}{l}\text { Memahami cara pengelolaan sampah plastik } \\
\text { yang benar }\end{array}$ & 0.00 & 0.00 & 10.71 & 21.43 & 67.86 \\
\hline $\begin{array}{l}\text { Mampu mengajarkan cara penanganan } \\
\text { sampah plastik ke orang lain }\end{array}$ & 0.00 & 7.14 & 14.29 & 17.86 & 60.71 \\
\hline
\end{tabular}

*Persentase respon 1 sampai 5 menunjukkan tingkat pemahaman, dari tidak paham (1) hingga sangat paham (5)

Kemungkinan pemanfaatan paving blok berbahan plastik untuk komersialisasi di masyarakat kemungkinan masih membutuhkan kajian lebih lanjut. Beberapa masalah yang ditemukan selama pelaksanaan adalah:

1. Pengadukan manual membuat wadah pelelehan plastik harus dibuka. Saat tutup dibuka, asap akan mengalir ke lingkungan. Asap ini seharusnya 
dialirkan ke pipa kondensasi sehingga tidak mencemari udara;

2. Cacahan sampah plastik harus benarbenar bersih dari material lain seperti logam, kertas, dan semacamnya. Keberadaan logam, kertas dan material lain membuat paving blok yang dihasilkan tidak tercampur secara merata;

3. Biaya yang dibutuhkan untuk pembuatan paving blok berbahan plastik masih lebih tinggi dibanding paving blok berbahan semen. Biaya per satu paving blok adalah sekitar empat ribu rupiah, sedangkan harga paving blok berbahan semen adalah sekitar seribu dua ratus rupiah. Biaya yang besar ini terutama untuk pembelian sumber energy (gas) pelelehan plastik, dan upah produksi yang masih tinggi karena jumlah unit yang dihasilkan per-jam masih sedikit. Penggunaan fasilitas yang lebih mapan kemungkinan dapat meningkatkan jumlah produksi per-jam ini.

Beberapa kelemahan lain dari produk yang dihasilkan adalah:

1. Gaya gesek yang kemungkinan kecil sehingga bersifat lebih licin. Masalah ini kemungkinan dapat diatasi dengan pembuatan cetakan bergerigi, atau penambahan koral di dasar cetakan.

2. Belum dilakukan uji ketahanan di iklim tropis. Belum ada data tentang usia paving blok berbahan plastik ini saat diletakkan di luar ruangan dalam kondisi panas dan hujan.

3. Perlu dilakukan uji ikatan paving blok dengan semen. Hal ini terutama diperlukan jika konversi sampah plastik ini nanti akan digunakan sebagai pengganti batu bata.

Namun demikian, metode konversi sampah plastik menjadi paving blok ini sangat efisien dalam memerangkap sampah plastik. Satu produk paving blok bervolume $45 \mathrm{~cm}^{3}$ mampu memerangkap sampah plastik hingga 750 gram sehingga tidak mencemari tanah dan perairan. Metode ini juga mengurangi kemungkinan penguraian lebih lanjut sampah plastik menjadi mikro- dan nanoplastik yang berakibat lebih berbahaya bagi lingkungan. Hasil konversi menjadi paving blok ini juga dapat digunakan sebagai struktur bahan bangunan sehingga memungkinkan untuk dilakukan secara berkelanjutan. Masalah asap dari proses pelelehan seharusnya dapat ditanggulangi dengan cerobong pendingin, sehingga asap yang berbentuk gas dapat terkonversi menjadi cair. Persoalan energi yang dibutuhkan untuk kegiatan pelelehan seharusnya dapat ditutupi dengan manfaat pengurangan limbah dan nilai jual produk yang dihasilkan.

Lebih lanjut, pelelehan sampah plastik akan mengurangi aktivitas pembakaran sampah plastik di udara terbuka. Pembakaran plastik menghasilkan gas yang lebih berbahaya disbanding metode pelelehan plastik (Ragaert et al., 2017). Bagi dunia pendidikan, kegiatan konversi sampah plastik menjadi paving blok ini mampu meningkatkan pemahaman dan sifat peduli peserta didik akan permasalahn sampah plastik di lingkungan sekitar. 


\section{KESIMPULAN}

Berdasarkan kegiatan pengabdian yang telah dilakukan, dapat diperoleh kesimpulan sebagai berikut:

1. Daya kuat tekan paving blok berbahan sampah plastik tidak berbeda dengan paving blok berbahan semen;

2. Kegiatan sosialisasi pembuatan paving blok berbahan sampah plastik ini mampu meningkatkan pengetahuan peserta didik akan pengelolaan sampah plastik sebesar 34\%.

3. Melalui kegiatan pengabdian ini, $89 \%$ peserta didik yang terlibat menyatakan paham tentang permasalahan sampah plastik di lingkungan global.

\section{Ucapan Terima Kasih}

Terima kasih kami ucapkan pada jajaran pimpinan FKIP Universitas Bengkulu yang telah mendanai kegiatan pengabdian ini melalui dana DIPA fakultas. Terima kasih juga kami ucapkan pada laboratorium terpadu Fakultas Teknik Universitas Bengkulu sebagai tempat pelaksanaan uji tekan. Terakhir, terima kasih kepada pimpinan, dewan guru, dan peserta didik di Pondok Pesantren Modern Darussalam Kepahiang yang telah membantu kami dalam mengadakan kegiatan pengabdian ini.

\section{Video Pengabdian :}

(https://youtu.be/TtroNoTqltA)

\section{DAFTAR PUSTAKA}

Ariyadi. (2019) Uji Pembuatan Paving Block Menggunakan Campuran Limbah Plastik Jenis PET (Poly Ethylene Terephthalate) Pada Skala Laboratorium, Universitas Negeri Raden Intan.

Basuki, B. \& Darmanijati, M. (2018) Pemanfaatan Limbah Plastik Bekas Untuk Bahan Utama Pembuatan Paving Block. Jurnal Rekayasa Lingkungan 18, 1-7.

Blair, R. M., Waldron, S., Phoenix, V. \& Gauchotte-Lindsay, C. (2017) Microand Nanoplastic Pollution of Freshwater and Wastewater Treatment Systems. Springer Science Reviews 5, 19-30.

Borrelle, S. B., Ringma, J., Lavender Law, K., Monnahan, C. C., Lebreton, L., McGivern, A., Murphy, E., Jambeck, J., Leonard, G. H., Hilleary, M. A., et al. (2020) Predicted Growth in Plastic Waste Exceeds Efforts to Mitigate Plastic Pollution. Science.
Ermawati, R. (2011) Konversi Limbah Plastik Sebagai Sumber Energi Alternatif. Jurnal Riset Industri 5, 257-263.

Geyer, R., Jambeck, J. R. \& Law, K. L. (2017) Production, Use, and Fate of All Plastics Ever Made. Science Advances.

Indrawijaya, B. (2019) Pemanfaatan Limbah Plastik Ldpe Sebagai Pengganti Agregat Untuk Pembuatan Paving Blok Beton. Jurnal Ilmiah Teknik Kimia 3, 1-7.

Jambeck, J. R., Geyer, R., Wilcox, C., Siegler, T. ., Perryman, M., Andrady, A., Narayan, R. \& Law, K. . (2015) Plastic Waste Inputs from Land into the Ocean. Science 1655-1734.

Kehrer, J. P. \& Biswal, S. S. (2000) The Molecular Effects of Acrolein. 15, 615. 
Klemeš, J. J., Fan, Y. Van, Tan, R. R. \& Jiang, P. (2020) Minimising the Present and Future Plastic Waste, Energy and Environmental Footprints Related to COVID-19. Renewable and Sustainable Energy Reviews.

Levin, B. C. (1987) A Summary of the NBS Literature Reviews on the Chemical Nature and Toxicity of the Pyrolysis and Combustion Products from Seven Plastics: AcrylonitrileButadiene-Styrenes (ABS), Nylons, Polyesters, Polyethylenes, Polystyrenes, Poly (Viny1 Chlorides) and R. Fire and Materials 11, 143157.
Mattsson, K., Hansson, L. A. \& Cedervall, T. (2015) Nano-Plastics in the Aquatic Environment. Environmental Sciences: Processes and Impacts 17, 1712-1721.

Ragaert, K., Delva, L. \& Van Geem, K. (2017) Mechanical and Chemical Recycling of Solid Plastic Waste. Waste Management 69, 24-58.

Salamah, S. \& Aktawan, A. (2016) Pemurnian Hasil Cair Pirolisis Sampah Plastik Pembungkus Dengan Distilasi Batch. Chemical 3, 31-34. 